\title{
Negotiating “Home:" Syrian and Palestinian Syrian Artists in Borderlands
}

\author{
Ruba Totah
}

\begin{abstract}
Since 2012, the escalation of the Syrian conflict has forced the displacement of millions of Syrians into neighboring countries, as well as Europe. Tens of artists moved out of Syria due to scarce employment opportunities and restrictions associated with working under oppressive regimes. Some of the interlocutors in this research emphasised their attempts to stay in Arab countries and reconstruct their "home" by resuming artistic careers, but ultimately decided to move to Europe, while others favoured leaving directly. This paper examines how, in the case of 16 artists' narrated life stories, various cultural institutions' support, life trajectories, and relational dynamics come together to influence home-making opportunities in Arab transit countries. It addresses the challenges, potentials, and implications of home-making attempts of displaced performing artists.
\end{abstract}




\section{Introduction}

In 2005, the global community adopted the Universal Convention on the Protection of the Diversity of Cultural Expressions, aiming to boost cultural industries around the world. Sixteen Arab countries ratified this convention and other cultural policies, ${ }^{1}$ in order to enhance artist's mobility and cultural exchange. Shared language and cultural references held opportunities for transnational cooperation in performing arts, especially in theatre, dance, and music. However, continuing mobility restrictions ${ }^{2}$ and repression of diversity in political productions exposed Arab regimes' pseudo-commitment to the exchange of arts. As of 2011, more and more Syrians became displaced, and challenges faced in refugeehood were exacerbated by restrictive policies ${ }^{3}$ adopted in 2014 on their mobility, residence, and work. ${ }^{4}$ This, in turn, provided insight on the various actors in the current Arab cultural production scene and shaped artists' trajectories. Among the displaced were performing artists who played a major role in the Arab contemporary creative scene. They have promoted political and humanitarian discourses of conflict, its cultural

\footnotetext{
${ }^{1}$ The Arab Cultural Unity Charter 1964 and ALESCO 1970.

2 Until the Arab uprising era in 2010, Arab borders policies obstructed rather than encouraged the mobility of artists. See: Mona Merhi, "Syrian Art Production Support Models and Sustainability Challenges," Website, Ettijahat, December 2018, available at: https://www.ettijahat.org/page/801[last accessed 21 March 2019].

${ }^{3}$ Arab countries ratified the non-binding Global Compact for Safe, Orderly and Regular Migration in 2018, except for Lebanon and Jordan, which both did not sign the Refugee Convention in 1951. They consider the arriving masses as guests, not legal refugees. Lebanon declared that the crisis is not to be governed by law, but by governmental decisions. Due to restrictive residency policies, $70 \%$ of Syrian refugees did not have valid legal stay in the country, and $90 \%$ of Palestinian refugees from Syria lacked valid residency documents. See: Carole AISharabati and Jihad Nammour, "Survey on Perceptions of Syrian Refugees in Lebanon," Beirut, Institut Des Sciences Politiques - USJ, 2015, available at: https://data2.unhcr.org/en/documents/download/45083 [last accessed 21 March 2019]; Sally Abi Khalil and Valentina Bacchin, "Lebanon: Looking ahead in times of crisis," Oxfam Discussion Papers, Beirut, Oxfam, 2015, p.1-40, available at: https://oi-files-d8-prod.s3.eu-west-2.amazonaws.com/s3fs-public/file attachments/dp-lebanon-looking-ah ead-time-crisis-141215-en 0.pdf [last accessed 21 March 2019].

${ }^{4}$ Maja Janmyr, "The legal status of refugees in Lebanon," Working Paper, Beirut, Issam Fares Institute for Public Policy and International Affairs, 2016, p.1-20, available at: https://www.aub.edu.Ib/ifi/Documents/publications/working_papers/2015-2016/20160331_Maja_Janmyr.p df [last accessed 20 March 2019]; Susan F. Martin, Rochelle Davis, Grace Benton, and Zoya Waliany, "International Responsibility-Sharing for Refugees," Knomad Working paper, 2018, Vol. 1(32), p.1-46; Lebanon Support, "Formal Informality, Brokering Mechanisms, and Illegality. The Impact of the Lebanese State's Policies on Syrian Refugees' Daily Lives," Beirut, Civil Society Knowledge Centre, 2016, available at: https://civilsociety-centre.org/resource/formal-informality-brokering-mechanisms-and-illegality-impact-leba nese-state\%E2\%80\%99s-policies [last accessed 21 March 2019].
} 
imaginary, ${ }_{6}^{5}$ and myth-making, and have been subjected to an extended marginalisation of culture $^{6}$ which caused cuts in budget ${ }^{7}$ allocated for the art sector in a context of conflict.

Similar to millions of displaced Syrians, performing artists who were forced to move to Arab countries such as the United Arab Emirates (UAE), Kuwait, Jordan, Lebanon, or Egypt, searched for a secure place. They did so by resuming their art, by networking, and by familiarising themselves with a new country and context. Among those were Palestinian Syrian performing artists, descendants of initially displaced Palestinian communities to Syria. ${ }^{8}$ Most of the sixteen artists applied for residency permits and sought employment within the local formal art market, or resorted to other means of (informal) livelihoods. In order to get legal residency, artists depended mainly on personal, and informal transnational networks established long before the Syrian uprising. These networks created job opportunities in neighboring cultural arenas.

However, in 2015, many Arab countries closed their borders to all refugees coming from Syria ${ }^{9}$ These political measures further disrupted artistic productions, ${ }^{10}$ and many artists found themselves trapped in Syria, with limited opportunities to work, due to censured freedom of expression, and risks of persecution by the regime or its allies. By then, notably as many refugees fled to Europe, Arab countries transformed into "borderlands," becoming temporary transit points for some artists. ${ }^{13}$ Borderlands are generally described ${ }^{14}$ as regions at both sides of a border, that have specific social and economic connections. However, Hess and Kasparek

\footnotetext{
${ }^{5}$ Cultural imaginary refers to the images and discursive forms through which a cultural community articulates itself and connects with its collective identity formation. See: Steve Spencer, Race and ethnicity: Culture, identity, and representation, Abingdon, Routledge, 2014.

${ }^{6}$ Mona Merhi, op.cit., 2018.

${ }^{7}$ The Syrian government minimised its - already relatively low - cultural budget by $25 \%$.

${ }^{8}$ The number of Palestinian refugees in Syria before the uprising in 2011 was around 600,000 refugees. See: Maher Charif, "Palestinian refugees in Syria Fully integrated, for Better and for Worse," Website, Palestinian Journeys, n.d., available at: https://www.paljourneys.org/en/timeline/highlight/6591/palestinian-refugees-syria [last accessed March 21 2019]. Moving to Arab countries was more challenging to them because they moved with refugee documents rather than passports.

${ }^{9}$ Maja Janmyr, op.cit., 2016; Susan F. Martin, Rochelle Davis, Grace Benton, and Zoya Waliany, op.cit., 2018; Lebanon Support, op.cit., 2016.

${ }^{10}$ Some artists pointed to opportunities relevant to political positions.

${ }^{11}$ Europe became an option to Syrians following the Dublin III agreement, which aimed to ensure equal acceptance of asylum seekers by member states of the European Union.

${ }^{12}$ In the case of the Arab countries analysed in this paper, notably in the light of Syrian arrivals, the links and relationships were not only limited to areas near the border, but entailed whole countries. As such, in this paper, countries will be analysed as borderland regions. Balibar describes borderlands not as small regions but as larger "overlapping open regions." Etienne Balibar, "Europe as borderland," Environment and planning D: Society and space, 2009, Vol. 27(2), p.190-215.

${ }^{13}$ Artists consider Europe as a liberal haven and a wider art market, but language barriers persisted, and many did not consider Europe as a destination when they first left Syria. Interviews with a male Syrian producer in Berlin, 2018, and with a male Syrian singer and actor in Munich, 2017.

${ }^{14}$ Susan F. Martin, Rochelle Davis, Grace Benton, and Zoya Waliany, op.cit., 2018; Daniel Meier, "Introduction to the Special Issue: Bordering the Middle East,"Geopolitics, 2018, Vol. 23(3), p. 495-504.
} 
analyse borders as "mobile, fluid, selective, and differentiated," are a "physical, ideological, and geographical construct, a region of intersection that is sensitive to internal and external forces that both integrate and differentiate communities and eras on both sides of the boundary line." ${ }^{, 6}$ For example, Lebanon shares a border with Syria, and its entire geographical space, not only regions close to the borders, was opened to displaced Syrians following the uprising in 2011. Moreover, both the Lebanese and the displaced communities engaged in social and economic relations inside Lebanon. This was also the case in Jordan and Egypt. Therefore, this paper analyses these entire countries as borderlands. Additionally, this paper illustrates that these borderlands are influenced by both local and international dynamics. Such dynamics usually integrate and differentiate communities, offer spaces for confrontation, for identity formation, and for subverting borders. ${ }^{17}$ For forcibly displaced artists, their life experiences are impacted notably by relational dynamics of making a new home across nation-state borders.

This research focuses on those who tried to reconstruct a home in (borderland) Arab countries, before deciding to leave for Europe, by analysing their home-making attempts - which include processes of creating familiarity, belonging and resuming career - as well as processes of integration, and policies impacting mobility. In previous literature, "home" is conceived as a relationship, characterised as a spatio-temporal socio-cultural order that creates orientation between people and their environment. It also includes feelings of security, belonging, and familiarity acquired through patterns of experience and behavior. ${ }^{18}$ Additionally home-making involves describing the self in a new ordered place, and may represent a socially desired identity, rather than an individual one. It therefore reflects both collective ideology and authentic personal experience. ${ }^{19}$ Furthermore, this paper investigates how civil society actors and for-profit production companies created a transnational relational space within the borderlands.

This paper builds on recent transnational migration studies focusing on nation states' border regulation power, individuals' trajectories within the border regulation power, and migration as

\footnotetext{
${ }^{15}$ Sabine Hess and Bernd Kasparek, "Under Control? Or Border (as) Conflict: Reflections on the European Border Regime," Social Inclusion, 2017, Vol. 5(3), p.58-68.

${ }^{16}$ Randy William Widdis, "Crossing an intellectual and geographic border: the importance of migration in shaping the Canadian-American borderlands at the turn of the twentieth century," Social Science History, 2010, Vol. 34(4), p.445-497.

17 Sabine Hess and Bernd Kasparek, op.cit., 2017, p.5.

${ }^{18}$ Akhil Gupta and James Ferguson, "Beyond "Culture": Space, Identity, and the Politics of Difference," Cultural Anthropology, 1992, Vol. 7(1), p.6-23; Vasiliki Theocharidou, Gary Clapton, and Lorraine Waterhouse, "Lost in Transition? Lived Experiences of Unaccompanied Afghan Minors in Greece," Master's thesis, Edinburgh, University of Edinburgh, 2016, available at: https://era.ed.ac.uk/handle/1842/22944 [last accessed 20 February 2019]; Kimiko Suda, "A Room of One's Own: Highly Educated Migrants Strategies for Creating Home in Guangzhou," Population, Space and Place, 2014, Vol. 22(2), p.146-157.

${ }^{19}$ Kimberly Dovey, "Home and Homelessness," In Irwin Altman and Carol M. Werner (eds.), Home Environments, Boston, Springer, 1985, p. 33-64.
} 
a driving force. ${ }^{20}$ A trajectory is considered here as a temporally ordered intervention of social and subjective processes, in the form of life events and transitions. ${ }^{21}$ Trajectories in transition cease to reflect interventions but rather focus on relational dynamics and negotiations of binaries within those interventions. Therefore, the paper examines the relationship between artists' home-making trajectories and the challenges of migrating towards other Arab countries. Also, unlike studies on protracted uncertainty, which focus on coping mechanisms and "waiting," this paper describes the temporal experience of displaced artists in their host Arab countries in order to analyse their home-(un)making mechanisms. The paper highlights these dynamics while considering migrant artists' cultural activism in recent years. ${ }^{23}$ Furthermore, the paper analyses how Arab art aesthetics, and state policies, impact (or shape) these dynamics. ${ }^{24}$

${ }^{20}$ Mirjana Morokvasic, "Transnational Mobility and Gender: A View from Post-wall Europe," Crossing Borders and Shifting Boundaries, 2003, Vol. 1, p.101-133; Thomas Faist and Başak Bilecen,

"Transnationalism - Updated," COMCAD Working Papers 158, Bielefeld, Universität Fakultät Für Soziologie, Centre on Migration, Citizenship, and Development (COMCAD), 2017, available at: https://nbn-resolving.org/urn:nbn:de:0168-ssoar-55393-5 [last accessed 10 April 2019]; Sabine Hess, "Border Crossing as Act of Resistance: The Autonomy of Migration as Theoretical Intervention into Border Studies," In Martin Butler, Paul Mecheril, Lea Brenningmeyer (eds.), Resistance, Subjects,

Representations, Contexts, Bielefeld, Bielefeld Verlag, 2017, p.87-100; Nina Glick Schiller, "Theorizing Transnational Migration in Our Times," Nordic Journal of Migration Research, 2018, Vol. 8(4), p. 201-212; Hein De Haas, Katharina Natter, and Simona Vezzoli, "Growing Restrictiveness or Changing Selection? The Nature and Evolution of Migration Policies," International Migration Review, 2018, Vol. 52(2), p. 324-367.

${ }^{21}$ Gerhard Riemann and Fritz Schütze, "Trajectory" as a basic theoretical concept for analyzing suffering and disorderly social processes," in D. R. Maines (Ed.), Social organization and social process: essays in honor of Anselm Strauss, New York, De Gruyter, 1991, p.333-357; Ursula Apitzsch, Lena Inowlocki, and Maria Kontos, "The method of biographical policy evaluation," In Ursula Apitzsch and Maria Kontos (eds.), Self-Employment Activities of Women and Minorities, 2008, p. 12-18; Matthias Wingens, A Life-course Perspective on Migration and Integration, Dordrecht, Springer, 2011.

${ }^{22}$ Catherine Brun, "Active Waiting and Changing Hopes: Toward a Time Perspective on Protracted Displacement," Social Analysis, 2015, Vol. 59(1), p.19-37.

${ }^{23}$ Lígia Ferro, Pedro Abrantes, Luisa Veloso, and João Teixeira Lopes, "Learning How to Work in the Arts Field In Portugal: A Biographical Approach To The Migrant Artists' Trajectories," RUDN Journal of Sociology, 2018, Vol. 18(3), p. 507-520; Azadeh Sharifi, "Theatre and Migration Documentation, Influences and Perspectives in European Theatre," Independent Theatre in Contemporary Europe, Bielefeld, transcript Verlag, 2017.

${ }^{24}$ Lisa Wedeen, Ambiguities of Domination: Politics, rhetoric, and symbols in contemporary Syria: With a new preface, Chicago, The University of Chicago Press, 1999; Rania Jawad, Theatre Encounters: $A$ Politics of Performance in Palestine, New York University, 2013; Ruba Totah, "Performing Arts and Social Change under Colonialism in in Palestine during the period 1960-2012: view on impact of religiosity and class on gender relations in performing art," Thesis, Birzeit, Birzeit University, 2013, available at: https://fada.birzeit.edu/bitstream/20.500.11889/1424/1/thesis 13102015 92219.pdf [Last accessed 6 April 2019]; Samer Al Saber, "Stages of Homeland: Remembered Ghosts - Haunted Memories," Website, Jadaliyya, April 2017, available at:

https://www.jadaliyya.com/Details/34147/Stages-of-Homeland-Remembered-Ghosts-\%E2\%80\%93-Haunt ed-Memories [last accessed 6 April 2019]; Ruba Totah and Krystel Khoury, "Theater against Borders: 'Miunikh-Damaskus'-A Case Study in Solidarity," Arts, 2018, Vol. 7(4), p. 90; Basma El Husseiny, "حال 
Specifically, this paper provides a socio-anthropological analysis of the lives of displaced performing artists attempting to create and join cultural social fields in Arab host states.

The paper uses transnational biographical interview analysis, ${ }^{25}$ to collect and analyse the narratives of 16 artists forced to leave Syria. It also relies on what Hess introduced as an "ethnographic regime approach" ${ }^{26}$ to analyse migrants' "transit biographies." Semi-structured interviews were conducted over two years (2017-2019) with artists currently living in several European countries. The group of artists in this study is heterogeneous. The artists, aged between 25 and 55, originated from various districts within Syria, with at least half of them from Damascus and with a minimum of five years of professional experience in the performing arts. Two artists were Palestinian Syrians, eight were women. The results relied on a comparison of "narrated life stories" of two case studies with those of the remaining artists. Using an empirically grounded approach, the paper describes the artist-identified experienced events processes, how artists structured those processes through actions, and led creative transformations. It comprises formal textual analysis, which deals with the narrative, argumentative, and descriptive excerpts from artist interviews.

This paper will first introduce actors providing economic and social support to artists. It then analyses sixteen artists' lived experiences to outline the relational dynamics of their home-making processes during migration, in an attempt to provide a subjective understanding of artists' integration processes in Arab countries.

\section{Institutional Support for Migrant Artists in Arab Countries: the Impact of Legal Residency Restrictions}

Twentieth-century art exchanges between Arab countries such as Lebanon, Syria, Jordan, Egypt, and Palestine ${ }^{27}$ were the result of unifications, colonial forced displacements, and civil wars. Until 2011, each nation-states' political and border regimes imposed tariffs on art materials and surveilled content to such an extent that it inhibited international co-productions. Consequently, the Arab performing arts industry was modest and lacked diversity. The various artistic styles shrunk into analogous art patterns, serving the dominant formal cultural output of the national regimes. $^{28}$

\footnotetext{
الفنون," Website, Jadaliyya, 15 February 2018, available at: http://www.jadaliyya.com/Details/35206/ الفالفنون [last accessed 6 April 2019]; Mona Merhi, op.cit., 2018.

25 "Biographicity" refers to a personal journey of self-development and connection to the social structure, including the ability to shape and reshape one's story about society. Catherine Cassell and Gillian Symon, Essential Guide to Qualitative Methods in Organizational Research, London, SAGE, 2012; Kathy Charmaz, Constructing Grounded Theory, London, Sage Publications, 2014; Ursula Apitzsch and Irini Siouti, "Transnational Biographies," Zeitschrift Für Qualitative Forschung, 2015, Vol. 15(1-2), p. 12-23. ${ }^{26}$ Sabine Hess, "De-naturalising transit migration. Theory and methods of ethnographic regime analysis," Population, Space and Place, 2010, Vol. 18(4), p. 428-440.

${ }^{27}$ Palestine's borders were complicated by policies as of 1948. Colonial and Arab borders policies clashed and changed rapidly over the decades.

${ }^{28}$ Ahmed Ibrahim Abushouk. "The Arab Spring: A fourth wave of democratization?," Digest of Middle East Studies, 2016, Vol. 25(1), p.52-69.
} 
Against this backdrop of restrictive political contexts, spurred by constraining migration policies, two groups of actors continued to support displaced artists in Egypt, Lebanon, and Jordan. The first group consists of non-profit institutions, such as cultural civil society organisations, and regional, and international cultural institutions, that reaffirmed the need for art during conflict. Arab cultural institutions attempt to remain independent from governments, and create spaces of freedom of expression for artists, such as the Cultural Resource, ${ }^{29}$ the Arab Cultural Fund (AFAC), ${ }^{30}$ Ettijahat-Independent Culture, ${ }^{31}$ and the Arab Education Forum. ${ }^{32}$ These institutions enabled artists to regain access to the Arab art scene ${ }^{33}$ by introducing additional programs in 2012, that support productions, grant regional travel funds, and promote collaboration and exchanges among artists. Despite these programs, these institutions have not managed to overcome restrictive residence and labour policies for artists in host countries. In addition, they were constrained by Arab governments' marginalisation of culture and oppressive responses to opposition expressed through art. This group also consists of international cultural institutions, ${ }^{34}$ such as the Goethe Institute (GI), the British Council, and the Ford Foundation, which have continued their historical and liberal relationship with the Arab culture sector in the neo-colonial era. They have promoted regional institutions' missions, implemented some programs, and facilitated artist mobility outside the Arab countries. ${ }^{35}$

The second group, which provides support for the creative production scene, consists of the for-profit drama and performance companies that lead mainstream Arab TV drama and entertainment, which have managed to create a new mainstream Pan-Arab trend in the drama industry. Contracted Syrian artists starring with Lebanese or Egyptian artists are known to receive the highest wages and viewing rates, granting them enough capital and prestige to obtain

\footnotetext{
${ }^{29}$ The Cultural Resource provides four grants to artists. These include the Red Zone grant which is an international platform for artists to present their work on topics related to borders, displacement, censorship, and other currently globally relevant ideas. See: Al Mawred Al Thaqafy, Website, Al Mawred Al Thaqafy, available at: http://mawred.org/ [last accessed 27 February 2019].

${ }^{30}$ The Arab Cultural Fund AFAC provides grants in various artistic fields to individuals or groups. See: Arab Fund for Arts and Culture, Website, Arab Fund for Arts and Culture, available at: https://www.arabculturefund.org/ [last accessed 27 February 2019].

${ }^{31}$ Ettijahat-Independent Culture was founded in 2011, it provides programs on Research Laboratory of Art, Create Syria, Amaken, and Ajyal. See: Ettijahat, Website, Ettijahat, available at: https://ettijahat.org [last accessed 27 February 2019].

32 The Arab Education Forum encourages mobility spaces and experiences exchange through Safar, Hakaya, Istikshaf programs. See: The Arab Education Forum, Website, The Arab Education Forum, available at: http://almoultaqa.com [last accessed 27 February 2019].

${ }^{33}$ Theatre groups continued their activities in Lebanon, such as the contemporary dance company Sima, the Koon theatre collective, and collaborations between Syrian and Lebanese artists multiplied. See: Emmanuel Haddad, "Contemporary performing arts in Lebanon: an overview," Website, IETM, March 2017, available at: https://www.ietm.org/en/publications [last accessed 27 February 2019]. ${ }^{34}$ The British Council had implemented HOPES since 2016, providing scholarships in arts fields. GI offered scholarships of language studies and exchange of theatre productions since the 1970s. Since 2015, Ford Foundation has been funding the Action for Hope initiative in Lebanon, inviting artists to exhibit in art galleries in the US.

${ }^{35}$ Interview with Hanan AIQassab, the former director of Higher Institute of Performing Arts in Syria, Antwerp, 20 October 2017.
} 
long-term residence in Lebanon or Egypt. In Jordan, Syrian musicians joined local bands and were contracted by (music) production companies for entertainment performances.

Artists' engagement with these cultural institutions and for-profit production companies determined their opportunities to get by in their host countries, and to cope with formal residency systems. Hind, a Syrian actress, explains: "I received an acting award in Egypt 2009, and then a job [offered by a production company] enabled me to move to Egypt in 2012." ${ }^{36}$ Both her former success and the job opportunity enabled her to leave Syria. Similarly, Nadi, a

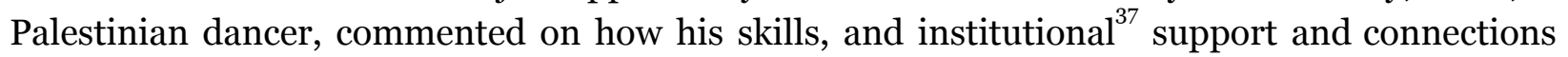
enabled him to move within Lebanon, being a Palestinian-Syrian. He explained: "Being affiliated with this institution, [and getting a legal status through them] helped me postpone my military service in Syria for two years, and whenever I passed by a checkpoint in Lebanon, they did not check me because I had a card saying that I worked with this institution."38

In other cases, artists emphasised that various factors (e.g. their legal status) impeded on their engagement with cultural institutions, which limited their opportunities to obtain support and benefit from networking. In the case of Maha, a dancer, her Palestinian refugee status prevented her from obtaining access to legal residency. This, in turn, hindered her access to work: "I was also famous in Egypt. I stayed there eight months to find a job. I did several interviews, but no one agreed to hire me. Because in the end, I am a [Palestinian] refugee and I had no legal residency papers in Egypt." ${ }^{39}$ Actor Amin also confirmed "I was waiting for my residence papers in Egypt, so I could not work. I had to keep a low profile while waiting, because the Egyptian regime declared Syrians unwelcome after 2016." ${ }^{40}$ As such, although some cultural institutions are able to provide a pathway for legal residency for migrant artists, (Palestinian) Syrian artists' lack of residency could also be a conditio sine qua non, completely hindering any collaboration, for others.

\section{Multi-Scalar Dynamics Affecting Artists in Borderlands}

Beyond the support of for-profit and non-for profit institutions, other factors and power dynamics impact artists' trajectories. These powers function within what Glick Schiller ${ }^{41}$ describes a "multi-scalar" social field, which consists of a group of networks of social relationships through which humans exchange and transform practices and resources processes that are constituted by time and space. This social field plays an important role in shaping refugees' response to displacement, for example by reconstituting their lives. It includes intersecting power dynamics of individuals, and migration authorities, as well as cultural and for-profit institutions. This field consists of three powers that impact the relational dynamics of performing artists within the borderlands, and the support that they receive. First, the allies of

\footnotetext{
${ }^{36}$ Interview by the author with female Syrian actress, Paris, 15 November 2017.

${ }^{37}$ The institution is based in Beirut, and its name is anonymised. It is famous for organising dance theatre that blends Arab with western dance heritage.

${ }^{38}$ Interview by the author with male Palestinian-Syrian dancer, Paris, 1 April 2019.

${ }^{39}$ Interview by the author with female Palestinian-Syrian dancer, Munich, 25 April 2018.

${ }^{40}$ Interview by the author with male Syrian actor, Berlin, 10 April 2018.

${ }^{41}$ Nina Glick Schiller, op.cit., 2018, p. 201-212.
} 
the Syrian regime in Arab countries influenced and monitored artists' political involvement in their productions. Artists have produced narratives linked to war, forced movement, and escape, by referring to specific occurrences of the conflict. Their activities were initially tolerated by the political regimes in the area, in line with a discourse of artists being free to tell their stories, and Arab audiences wanting to hear them. However, the political regimes ${ }^{42}$ did not tolerate these productions, which narrowed artist's opportunities to work, as expressed by the actress Hind: "[Among those] who are against the regime; no one is working."

The second factor constituting the social field includes artists' personal, social, and cultural capital that they brought along from Syria, which can mainly be linked to the Higher Institute for Theatre Arts (HITA) in Damascus. Syrian drama and TV productions have long been engaging graduates from HITA, whose projects usually gain top viewing rates, and are considered a highlight in the Arab area. Having gained a prestigious inter-Arab reputation, HITA promoted artists social and cultural prestige, ${ }^{44}$ and facilitated access to local projects in neighbouring countries, for Syrians who had fled. ${ }^{45}$

Third, new trends in global art marketing and distribution in the borderlands play an active role in the social field. Artists' displacement has prompted international cultural organisations to adopt a more active role to support artists during the crisis. Ebert, the director of the Damascus branch of Goethe Institute (GI) explains, "We feel paralysed, but we find that what we do [in Syria and the neighbouring countries], is a huge responsibility given these circumstances. We want to offer help through education and cultural programs for artists. ${ }^{~} 46$ As such, participation in the global market for displaced artists in borderlands, such as Lebanon, Egypt, and Jordan, increased significantly. For example, GI has connected displaced artists with each other and has promoted artistic productions globally. Another GI representative said, "Our aim was to create a platform for Syrian and international artists to engage in dialogue. Several projects are

\footnotetext{
${ }^{42}$ Many productions are judged based on artists' political affiliations and not on artistic quality. Selections of works nominated for prizes, invitations to festivals and talk shows in the past ten years mostly include artists affiliated to the political regimes of Syria and Egypt. Artists silent on the conflicts were soon pushed to declare support to one side, based on cooperation with their affiliates.

${ }^{43}$ Interview by the author with the artist, Paris, 1 April 2019.

${ }^{44}$ HITA, founded in 1977, has a leading role in performing arts teaching in the Arab area. All artists in this study engaged with it academically, except for two who were part of other schools in other districts.

${ }^{45}$ Hanan Alhaj Ali, "Introduction to the cultural policy profiles of Algeria, Egypt, Jordan, Lebanon, Morocco, Palestine, Syria and Tunisia," Cultural Policies in Algeria, Egypt, Jordan, Lebanon, Morocco, Amsterdam, The European Cultural Foundation, 2010, p.23-25, available at: https://www.culturalfoundation.eu/library/cultural-policies-algeria [last accessed 20 March 2019]. ${ }^{46}$ Opening of a project 'Goethe Damaskus im Exil' in Berlin 2016 shortly after artists arrival from the Arab countries. The project included Syrian and German artists meeting to enhance networking between them after closing GI in Damascus. See: Goethe-Institut,"Eröffnung Goethe-Institut Damaskus | Im Exil Deutsch," Online video, Youtube, October 20, 2016, available at: https://www.youtube.com/watch?v=XbMW_iMLdeQ [last accessed 20 July 2017].
} 
organised in countries such as Lebanon and Turkey, to create perspectives beyond war and crisis." $^{47}$

Although presented as a humanitarian responsibility, such networks are utilised by organisations such as GI to feed into the international refugee art market by attracting funds and mobilising resources around the art produced by refugees. However, by reviving this market, GI and other international organisations also accumulate a socio-economic capital, which was the result of cultural hybridisation that GI had promoted in the postcolonial era. The historic resourcefulness of the GI in keeping networks, introducing and linking Syrian artists to other international art scenes, has encouraged its role in mediating artists traveling outside the Arab countries when they are no longer able to stay in them. As such, eventually, intentionally or not, institutional support can contribute to artists' mobility.

In the next section, I will provide an in-depth analysis of artists' experiences to gain an understanding of how multi-layered power dynamics within the art scene impacted artists' cognition of borderland regimes and their home-making trajectories.

\section{Trajectories of Constructing "Home" in the Borderlands}

After being displaced from Syria, artists initially remained in Arab countries in which they were familiar with the art schools, institutional mechanisms, and the language. This increased the potential for networking opportunities. Artists' choices were also based on the search for a sense of community with peers in Arab performing arts networks. This emotional bonding provided the basis for establishing a new home. The subjective home-making experiences reveal artists' diverse attitudes towards the multi-scalar powers they faced, related to (allies of) the Syrian regime; artists' personal, social, and cultural capital; and new trends in global art marketing and distribution (see previous section). The following excerpts from artists' biographies provide two specific narratives from migrant artists who spent over a year in an Arab country, one being male (Munir) and one female (Hind). Their narratives are deconstructed into actions, patterns, and arguments around actions, which are then used to explain artists' life trajectories, including attempts to settle, resume a career, and to create the familiarities of a new home. These trajectories create relationships between the artists and the surrounding institutional and migratory systems. They describe the relational dynamics that emerge in the borderland space regarding the migrant's agency in actions, arguments, decisions, and self-disclosure. In addition, agency refers to "understanding decision-making, room to maneuver, opportunity structures, and migration trajectories." ${ }^{48}$ This definition explicitly links to institutional support, notably within the opportunity structure of migrant artists.

The following section analyses the extent to which the relational dynamics of transnational space contribute to artists' home-making in the borderlands.

\footnotetext{
${ }^{47}$ Renate Heilmeier, "Questionnaire on Goethe-Institut Damaskus im Exil," received by Ruba Totah, 22 June 2017.

${ }^{48}$ Bridget Anderson and Martin Ruhs, "Researching illegality and labour migration," Population, Space, and Place, 2010, Vol.16(3), p.175-179.
} 


\section{Deconstructing Artist Accounts as they Navigate the Multi-Scalar Social Field}

Artists' pathways to establish a home in Arab host countries include patterns of action and cognitive adaptation to new regimes. Hind left Syria following threats and repression by security authorities in 2012. She moved with her daughter to Egypt to pursue an employment contract. Being a single mother in Egypt, in some aspects considered an unstable country, she suffered from a lack of mobility and livelihood insecurity when her contract was not extended. In 2013, she received a new employment offer in Lebanon and moved there with her daughter for a year and a half. In Lebanon, she noticed that joining new projects was difficult due to her stance on the Syrian politics, and she found life there difficult and expensive. She illustrates:

"After a one-and-a-half year stay in Lebanon, I noticed that after the project I had completed, nobody approached me again. I saw others working, and it became clear to me that artists who are against the regime are not welcomed in the Arab or Syrian projects running outside Syria. This realisation became clear to me. [...] It is also less of a headache for the producing companies who avoid contracting us, because eventually they will be interrogated about the reasons why they contracted those from the opposition." 49

Thus, financial, personal, and political security were all lacking, rendering long-term settlement in Lebanon unfeasible. She adds: "There is a difference between one artist and the other [...]. I did not reach the point of selling [of my own art], and I never wanted to. I did well-received works that the public admired a lot, but not with the purpose of becoming a seller. ${ }^{, 50}$ Therefore, she applied for asylum with a United Nations agency. She was accepted with a refugee status in France, and left Lebanon.

Munir left Syria before the 2011 uprising, after receiving a job offer in Jordan. He stayed there for four years, received subsequent offers, and shifted from opera to entertainment. This changed as of 2015, when all mobility between Arab countries was restricted for Munir and his family, being Syrians. Yet, returning to Syria, where he faced conscription into the Syrian army, was not an option, either. Unbearable border procedures pushed him to find opportunities to travel to Sweden, to seek asylum:

"I stayed in Amman for two years and worked in the entertainment industry for a living. [...] Then, I received a choir offer with an institution in Jordan:I performed the solo in the performance they produced. [...] After that, I continued working in the entertainment art for months, in Jordan. Over time, however, I realised that my Syrian passport was becoming meaningless through every humiliating and provoking incident with security guards in airports, and everywhere I traveled. I needed to travel for work a lot, so I realised that I needed papers to help me to overcome the mobility hassle, which became unbearably annoying. My sister was already in Sweden, so I went there by plane. There, I

\footnotetext{
${ }^{49}$ Interview by the author with female Syrian actress, Paris, 15 November 2017.

${ }^{50}$ Interview by the author with female Syrian actress, Paris, 15 November 2017.
} 
was depressed for almost a year and three months, which had already started in Amman."

Both Munir's and Hind's narratives describe coping with change by taking action. Although institutional support triggered their journeys, safety concerns and prospects of better livelihoods contributed to their attempts to resettle in Egypt, Jordan, and Lebanon. Indeed, their resettlement attempts were not anticipated, full of conflicting emotions, transformations, successes and failures, and were reactions to the circumstances unfolding around them. For example, Hind reacted to oppression in Syria by leaving, and when she could no longer stay due to employment and social insecurity in Egypt, she resettled in another Arab country, namely Lebanon. Munir, too, repeatedly attempted to revisit Syria. In order to avoid the army subscription, he switched tactics to get his mother to visit him in Jordan, instead. Furthermore, as his work in the entertainment sector required him to travel to several Arab countries, in a context of increased travel restrictions, he changed fields from opera to entertainment, which he was able to perform without traveling, inside Jordan. The multiple trials and attempts that displaced artists engage with, are qualified here as patterns of actions and reactions. These patterns reflect artists' agency in searching for socially and politically secure spaces, while trying to secure their career. Such process of agency should not be analysed as "agency in waiting"52 which refers to a proactive attitude during their temporary stay. Instead, it relates to artists' active intention of settling in the new place.

Furthermore, Munir's and Hind's narratives reveal the capacity of artists to justify their repeated attempts to find stability at the borderlands. Hind emphasised the impact of Syrian political allies on art production and how it contributed to feelings of fear, even in a neighboring country. She elaborates: "I was afraid at any moment, [that the regime or its allies] would play this game [in which they use arts to detect political opponents], and we would become a card in it.",53 Political alliances repeatedly jeopardised her artistic reputation, not only by denying her work opportunities, but also by (informal) defamation. She also described transformations in gender relations and the challenging gender dynamics of being a single mother in Egypt: "You become the mother, the father, you should be sensational and strong, and create a comfortable atmosphere in the house, which means you become everything, so it was tough."

Munir provides similar justifications for his actions and reactions in the borderland. He described the art market for Syrians in Arab countries, by using terms such as "humiliating," "meaningless," "hassle," and "unbearably annoying." "His attempts to settle in Arab countries reflected experiences of being subjected to a multi-layered political and economic system of power, for example by being unable to return to Syria out of fear for obligatory military service,

\footnotetext{
${ }^{51}$ Interview by the author with male Syrian actor and singer, Munich, 27 May 2017.

${ }^{52}$ Catherine Brun, op.cit., 2015, p.19-37.

${ }^{53}$ Interview by the author with female Syrian actress, Paris, 15 November 2017.

${ }^{54}$ Interview by the author with female Syrian actress, Paris, 15 November 2017.

${ }^{55}$ Interview by the author with male Syrian actor and singer, Munich, 27 May 2017.
} 
or by switching to entertainment music productions. Similarly, he argued that mobility restrictions limited his possibilities for institutional support in Jordan.

The next section will examine two different trajectories to reconstruct a new home in Arab countries. Following Riemann and Schütze's defitionion, a trajectory is considered a temporally ordered intervention of social and subjective processes, in the form of life events and transitions.

\section{Emotional Identification within Borderlands and Career Compromises}

Artists' arguments illustrate emotional identification within the borderlands. Their presence in an Arab country, which was somehow related to cultural and geographic proximity, aroused different emotional states among interviewees. ${ }^{57}$ For example, Hind describes Beirut with feelings of nostalgia, by referring to "all the history it holds that connects us [Syrians and Lebanese] since childhood, and the emotions it brings by visiting it." ${ }^{8}$ Munir said: "I was close with the people I met in Amman, and I found the art field I was looking for. It was close to Syria, so I could always visit." ${ }^{, 59}$ Both Hind's and Munir's experiences include proximity, shared memories $^{60}$ and language in the borderland.

Driven by such emotional identification, artists described their actions as reactions, constructing loops, and formulating them as spatial processes repeating throughout the journey of establishing a secure settlement. In the face of challenges related to migration and changing cultural contexts, emotional identification included compromise, maneuvering, and patience as behavioral patterns of coping with change. Hind searched for security and work in Egypt, and then in Lebanon. She received limited work offers from institutions in Lebanon, due to her political position. By repeatedly identifying with her choices through patterns of compromise and patience, Hind aimed to perceive Lebanon as "home," through building social relations. Her identification within the borderland transforms the borderland into a space enabling negotiation of career and security. Such practices shape home beyond its physical explanation. ${ }^{61}$ Munir also exhibits repeated actions to cope with mobility restrictions and fluctuating institutional support. The circuit of his actions, like Hind, describes spatial processes consisting of compromises, transformation, and maneuvering. He maneuvered by transforming his performance style and career choices. This reveals a capacity to transform the borderland into a space that transmutes his artistic identity and career. This spatio-temporal process of repeating compromises,

\footnotetext{
${ }^{56}$ Gerhard Riemann and Fritz Schütze, op.cit., 1991; Ursula Apitzsch, Lena Inowlocki, and Maria Kontos, op.cit., 2008; Matthias Wingens, op.cit., 2011.

${ }^{57}$ For decades, the "Arab Homeland" discourse has been promoted in schools and published materials, speeches, etc. This related to Anderson's "imagined community," connected by language mainly, and by religious cultural references promoted by the Arab regimes.

${ }^{58}$ Interview by the author with female Syrian actress, Paris, 15 November 2017.

${ }^{59}$ Interview by the author with male Syrian actor and singer, München, 27 May 2017.

${ }^{60}$ Re-memory as a process of remembering transmitted through family members and in discourses; see: Divya Tolia-Kelly, "Locating processes of identification: Studying the precipitates of re-memory through artifacts in the British Asian home," Transactions of the Institute of British Geographers, 2004, Vol. 29(3), p.314-329.

${ }^{61}$ Alison Blunt and Ann Varley, "Geographies of home," Cultural Geographies, 2004, Vol. 11(1), p. 3-6.
} 
movement, and transformations constructed a sense of familiarity, a new understanding that complied with the borderland system.

These behaviors relate to Brun's analysis ${ }^{62}$ of protractedly displaced people, who lose certainties about the past and future, while practicing routinised survival strategies in their refuge. Brun explains the importance of temporality in understanding people's experiences of uncertainty, which discourages mobility and settlement in exile. However, artists' repeated domestication of the new space, through social relations and negotiations, seek to re-establish certainties about their situation. Identification is an approach that attempts to reclaim control of living stability and career-building without relying on waiting and hoping, and without relying on strategies like faith, precaution, or avoidance. ${ }^{63}$ Rather, it relies on memory and the diverse resources of artists in the borderland.

Other artists also constructed narratives around patterns of identification. Five artists repeated attempts to re-establish a career in several Arab countries, and described processes of compromise, maneuvering, and transformation as home-making tools. Mona, an actress, explained she had "roles in Jordan with contractors whom I always refused to work with, because of the low-quality art they offered. I even lived off the food basket that the humanitarian agencies offered." ${ }^{64}$ A dancer described that as a Palestinian Syrian artist, she repeatedly negotiated mobility and residence procedures in the UAE, Lebanon, and Egypt, but still could not find a job. She argued, "this was frustrating to me, but I did not stop trying, because I felt that it is my right to have a place somewhere." ${ }^{25}$ Three other artists described how they repeatedly negotiated security systems by moving with fake names and hiding from security services. ${ }^{66}$ They compromised critically lowered financial and living conditions in Jordan, Egypt, and Lebanon for the sake of the art they were producing. The audience's praise for one of their performances led to financial support from two institutions for some individuals in the group. Ayman, another actor, explains: "one got a fund [...] for writing the script, and the other got another fund for directing it. To find a way to finance the whole project from these two funds, we all stayed in one small house." In these borderlands, artists changed fields, moved location, and followed work offers in an attempt to establish a new home, while maintaining their social and cultural activities and networks. Being in an Arab country enabled faster re-connection to platforms, and professional networks lost through war that could help reclaim their status as artists in a new home.

Thus, they started to identify (accept and emotionally relate) with their new situation of being caught between their home country Syria and their current country of residence. Identifying, allowed them to be able to continue to pursue their careers. Furthermore, it operates as an underlying motivation that infuses a process of transition in understanding of "home" which

\footnotetext{
${ }^{62}$ Catherine Brun, op.cit., 2015, p.19-37.

${ }^{63}$ Cindy Horst and Katarzyna Grabska, "Flight and Exile-Uncertainty in the Context of Conflict-Induced Displacement," Social Analysis, 2015, Vol. 59(1), p.1-18.

${ }^{64}$ Interview by the author with female Syrian actress, Paris, 1 April 2017.

${ }^{65}$ Interview by the author with female Palestinian-Syrian dancer, Munich, 25 April 2018.

${ }^{66}$ Interview by the author with male Syrian dramaturg, and actor-producer, Berlin, 10, 11 April 2018.
} 
encourages artists' agency in negotiating the multi-scalar power system in the borderlands. It opened pathways for discussion, in order to understand and justify artists' positions and possibilities in their new homes. Spatio-temporal processes of compromise, patience, transformation, and maneuvering are home-making tools that allow artists to construct concepts of survival, security, and mobility. Cultural institutions mediated their access to these home-making tools and processes. These tools describe the relational dynamics between artists and the borderland regime, whereby identification creates a basis for the continued negotiation of representing the self and "home." It describes a borderland home-making space comprising negotiated mixing of both the original home space and new home space.

\section{Disentanglement from Prior Understandings and Networks}

Disentanglement, the second trajectory in home-making attempts, refers to reversed processes that untie actors from a given relationship, whereby such detachment is deliberate and includes transformation. In the borderland, a multi-scalar social field refers to the process through which artists reconstruct their individual and political awareness, as well as peer and institutional networks, while disconnecting from prior understandings. Artists participated in the uprisings and their productions: quotes from their speeches were transmitted widely, which turned them into influential contributors to the popular culture ${ }^{67}$ of the uprising. Their participation reinforced their sense of collectivity and connection with peers inside Syria. However, their narrated actions in borderlands describe a process of disentanglement from these connections after displacement. This is due to the fact that they developed new individualistic understandings of themselves (including concepts of belonging, political awareness etc.). Munir said, "In Jordan, I discovered this idea that I can live without a nation-state, without belonging to a religion or nationality, the human aspect of me, not the national." ${ }^{68}$ Hind also referred to this disentanglement: "I decided to leave and live my life." country caused artists to de-prioritise traditional home-making mechanisms, such as owning a house. Artists developed new realisations of concepts of belonging to, and responsibility toward, their home in their host country.

In addition to individual disconnection, new realisations enabled artists to reconstruct their broader political awareness. Hind selects words like "I noticed," "I realised," "clear to me," "70 that illustrate her growing agency to decide to end her stay in the borderland. Also, Munir's increased awareness about his legal situation and work opportunities in Jordan aided his decision to leave. The more individual the narration of Munir and Hind became, the more the artists used their time in the borderland to remove themselves from belonging to its space. Artists used institutional support to disentangle from belonging to the borderland, particularly when it enabled them to travel. Institutional actors, which earlier promoted identification with borderland social and power structures, shifted their function to aid artists' disentanglement

\footnotetext{
${ }^{67}$ Writers, Singers and songs of the uprising are iconised in the media about the uprising. For example, Memes and audio-visuals on social media also contributed to the process of myth making.

${ }^{68}$ Interview by the author with male Syrian actor and singer, Munich, 27 May 2017.

${ }^{69}$ Interview by the author with female Syrian actress, Paris, 15 November 2017.

${ }^{70}$ Interview by the author with female Syrian actress, Paris, 15 November 2017.
} 
from the system. A university teacher confirms, "we tried to help artists find connections outside the Arab area to facilitate their travel." ${ }^{71}$

Interviews with other artists demonstrated similar narrative construction regarding disentanglement. By expressing openness to possibilities, some artists weighed their options between freedom of speech in borderland host countries and Europe. Imad, an actor and producer, said, "mediums for artistic expression shrank in the Arab countries and those who stayed, had to abide by governments or the civil society around it. I was [also] subject to this pressure in the United Arab Emirates." 72 Mona also explained, "In Syria, I managed to have some links to make bureaucracy easier on me, but in Jordan I couldn't restart my theatre project." ${ }^{, 3}$ Furthermore, artists referred to peers as distant and functional within the Arab art scene. The more detached artists became from the collective, the more they made decisions to leave the borderland. Disentangling enabled actors' distance from their roles in constructing a Syrian cultural imaginary and reframed their compromises in establishing a new home. By redefining and rethinking their peers' roles and influences, artists described disentanglement from prior conceptions about the self and peers. This stimulated a re-negotiation of the self and the other and feelings of belonging in the borderland.

The above analysis of individual narratives illustrates the relational dynamics which enabled artists' construction of space within borderland regimes. Artists continuously shift between describing actions and their limitations, while drawing on arguments to cross limiting beliefs about the self and others. One the one hand, identification includes artist involvement in situations, procedures, and resource accumulation processes which represent home-making. On the other hand, disentanglement refers to openness to new possibilities, to new understandings of the "self" and the "other," and new political awareness affecting artists' dynamic depiction of the borderland as a home. As such, these trajectories - somehow contradictory, but experienced in parallel - transformed the borderland regime into a space of relational experience. It is an experience of transformation of self-understanding, whereby agents must reconsider their habitual routines by simultaneously maneuvering, changing, showing patience, and encountering individuals and systems. Institutions supporting artists at the borderlands played mediating roles in contradictory trajectories - sometimes promoting identification, and other times encouraging disentanglement. It is within this relational turbulence that artists' home-making and un-making unfolds in a borderland.

\section{Conclusion}

Relational dynamics in the experiences of artists in this study correspond to what Gelfand et al. ${ }^{74}$ consider as the cognitive process of filtering and remembering of life experiences, which

\footnotetext{
${ }^{71}$ Interview with Hanan Al Qassab the Former director of Higher Institute of Performing Arts in Syria, location, 20 October 2017.

72 Interview by the author with male Syrian producer, Munich, 28 April 2018.

${ }^{73}$ Interview by the author with female Syrian actress, Paris, 1 April 2017.

${ }^{74}$ Michele J. Gelfand et. al, "Negotiating Relationally: The Dynamics of the Relational Self in Negotiations," Academy of Management Review, 2006, Vol. 31(2), p.427-451.
} 
envision the self in relation to others. They also correspond to what $\mathrm{Al}$ Ariss and Sayed ${ }^{75}$ regard $^{2}$ as a process including the agency of migrants, as well as the structural and institutional influences shaping their reality. They describe the practical intervention on the concept of the "transnational space" and refer to migrants' confrontation, negotiation, and identity-shaping within the multi-scalar structure of power at the borderland. These structures often include political alliances, institutional support, the impact of the neo-liberal global market, and artists' social and cultural capital. Artists' attempts to construct a new home in this transnational space are shaped by the opportunities and negotiations within this structure.

Thus, this paper contributes to an understanding of home-making trajectories in borderlands being formed by negotiating and rethinking traditionally accepted understandings of career paths and belonging. Embedded in the borderland transnational power structure, institutional support provided opportunities enabling the artists' negotiations. Analysis of artists' trajectories at the borderland space revealed that cultural institutions promoted artists' emotional identification and produced new forms of belonging through career choices. This analysis also showed that cultural institutions at the same time contributed to artist disentanglement from prior social and political understandings and networks, which generated new attitudes towards peer relationships, belonging, and careers.

As a result, home-making trajectories within this borderland space challenge the potential of integration as a concept; i.e. a process of complying with the host society's social, financial, and language requirements upon individuals. ${ }^{76}$ The analysis concludes that, as artists compromised their careers to identify with necessities of the host society, they have consequently produced new understandings about networks of peers and professions, in the society which obstructed their integration. Generally, the temporality of artists' experiences in borderlands, notably in an increasingly restrictive migration context in Arab areas and beyond, can be analysed as Glick Schiller's" "historical conjuncture." This entails the social, political, and economic transformations of the post-2011 area and reflects on the role of artists in borderlands.

In addition, artists' trajectories encourage discussing home-making as a transformative relationship. In this paper, artists' life trajectories negotiate home as a tool for creating the order required to achieve security, career progression, and belonging. It is a turbulent relational space in the historical conjuncture of the Arab area, which ultimately affects the capabilities of artists, as well as their productions. If, by definition, a boundary maintains territories that control or

\footnotetext{
${ }^{75}$ Akram Al-Ariss and Jawad Syed, "Capital Mobilization of Skilled Migrants: A Relational Perspective," British Journal of Management, 2010, Vol. 22(2), p. 286-304.

${ }^{76}$ Matthis Schick et. al, "Challenging future, challenging past the relationship of social integration and psychological impairment in traumatized refugees," European Journal of Psycho-traumatology, 2016, Vol. 7, p.1-9; Erik Snel, Godfried Engbersen, and Arjen Leerkes, "Transnational involvement and social integration," Global Networks, 2006, Vol. 6(3), p. 285-308; Alaster Ager and Alison Strang,"Understanding Integration: A Conceptual Framework," Journal of Refugee Studies, 2008, Vol, 21(2), p.166-191.

${ }^{77}$ Nina Glick Schiller, op.cit., 2018, p. 201-212.
} 
govern goods and people ${ }^{78}$ through mechanisms of inclusion and exclusion, the artists' trajectories to establish a home in the borderland negotiated the temporality and spatiality of this boundary.

In sum, this paper illustrates how, for Syrian and Palestinian Syrian artists in borderlands, institutional actors and relational dynamics influenced their home making opportunities. Artists faced significant challenges in conducting their work, in addition to work and residency permit restrictions. For example, cultural mobility has been historically marginalised and was further repressed following the Syrian uprising. Furthermore, cultural institutions providing support for artists in borderlands provided significant support to artists to resume their work. However, their programs and funds have been limited in scope and duration and are not able to circumvent migration systems. As such, the temporality of their programs limited the space for integration and cultural and creative agency. Moreover, the support of these cultural institutions may have contributed to artists' agency to disentangle themselves from borderland's social networks, by engaging them in global market networks which aid artists in unstable regions. In a borderland regime, representations of artists, refugees, and refugee-artists in transit societies are negotiated. The implications of migration, integration, and diversity are stretched beyond common norms. Further research is encouraged to track, and possibly contrast, negotiation processes of the self and home in countries where artists settled after the borderlands.

\section{Acknowledgements}

The author appreciates the insights by the anonymous reviewers and the co-editors to make the paper more coherent.

\section{References}

Ahmed Ibrahim Abushouk. "The Arab Spring: A fourth wave of democratization?," Digest of Middle East Studies, 2016, Vol. 25(1), p.52-69.

Alaster Ager and Alison Strang,"Understanding Integration: A Conceptual Framework,"Journal of Refugee Studies, 2008, Vol, 21(2), p.166-191.

Bridget Anderson and Martin Ruhs, "Researching illegality and labour migration," Population, Space, and Place, 2010, Vol.16 (3), p.175-179.

Kay Anderson, Handbook of Cultural Geography. London, Sage, 2003.

\footnotetext{
${ }^{78}$ Henk Van Houtum, Olivier Thomas Kramsch, and Wolfgang Zierhofer, Bordering Space, Burlington, VT: Ashgate, 2005; Robert David Sack, Human Territoriality: Its Theory and History, Cambridge, Cambridge University Press, 1986; Kay Anderson, Handbook of Cultural Geography. London, Sage, 2003.
} 
Ursula Apitzsch, Lena Inowlocki, and Maria Kontos, "The method of biographical policy evaluation," In Ursula Apitzsch and Maria Kontos (eds.), Self-Employment Activities of Women and Minorities, 2008, p. 12-18.

The Arab Education Forum, Website, The Arab Education Forum, available at: http://almoultaqa.com [last accessed27 February 2019].

Arab Fund for Arts and Culture, Website, Arab Fund for Arts and Culture, available at: https://www.arabculturefund.org/ [last accessed 27 February 2019].

Akram Al-Ariss and Jawad Syed, "Capital Mobilization of Skilled Migrants: A Relational Perspective,” British Journal of Management, 2010, Vol. 22(2), p. 286-304.

Etienne Balibar, "Europe as borderland," Environment and planning D: Society and space, 2009, Vol. 27(2), p.190-215.

Alison Blunt and Ann Varley, "Geographies of home," Cultural Geographies, 2004, Vol. 11(1), p. 3-6.

Catherine Brun, "Active Waiting and Changing Hopes: Toward a Time Perspective on Protracted Displacement," Social Analysis, 2015, Vol. 59(1), p.19-37.

Catherine Cassell and Gillian Symon, Essential Guide to Qualitative Methods in Organizational Research, London, SAGE, 2012.

Maher Charif, "Palestinian refugees in Syria Fully integrated, for Better and for Worse," Website, Palestinian Journeys, n.d., available at: https://www.paljourneys.org/en/timeline/highlight/6591/palestinian-refugees-syria [last accessed March 21 2019].

Kathy Charmaz, Constructing Grounded Theory, London, Sage Publications, 2014.

Kimberly Dovey, "Home and Homelessness," In Irwin Altman and Carol M. Werner (eds.), Home Environments, Boston, Springer, 1985, p. 33-64. 2019].

Ettijahat, Website, Ettijahat, available at: https://ettijahat.org [last accessed 27 February

Thomas Faist and Başak Bilecen, "Transnationalism - Updated," COMCAD Working Papers 158, Bielefeld, Universität Fakultät Für Soziologie, Centre on Migration, Citizenship, and Development (COMCAD), 2017, available at: https://nbn-resolving.org/urn:nbn:de:0168-ssoar-55393-5 [last accessed 10 April 2019]. 
Lígia Ferro, Pedro Abrantes, Luisa Veloso, and João Teixeira Lopes, "Learning How to Work in the Arts Field In Portugal: A Biographical Approach To The Migrant Artists' Trajectories," RUDN Journal of Sociology, 2018, Vol. 18(3), p. 507-520.

Michele J. Gelfand et. al, "Negotiating Relationally: The Dynamics of the Relational Self in Negotiations," Academy of Management Review, 2006, Vol. 31(2), p.427-451.

Goethe-Institut,“Eröffnung Goethe-Institut Damaskus | Im Exil - Deutsch,” Online video, Youtube, October 20, 2016, available at: https://www.youtube.com/watch?v=XbMW iMLdeQ [last accessed 20 July 2017].

Akhil Gupta and James Ferguson, "Beyond "Culture": Space, Identity, and the Politics of Difference," Cultural Anthropology, 1992, Vol. 7(1), p.6-23.

Hein De Haas, Katharina Natter, and Simona Vezzoli, "Growing Restrictiveness or Changing Selection? The Nature and Evolution of Migration Policies," International Migration Review, 2018, Vol. 52(2), p. 324-367.

Emmanuel Haddad, "Contemporary performing arts in Lebanon: an overview," Website, IETM, March 2017, available at: https://www.ietm.org/en/publications [last accessed 27 February 2019].

Hanan Alhaj Ali, "Introduction to the cultural policy profiles of Algeria, Egypt, Jordan, Lebanon, Morocco, Palestine, Syria and Tunisia," Cultural Policies in Algeria, Egypt, Jordan, Lebanon, Morocco, Amsterdam, The European Cultural Foundation, 2010, p.23-25, available at: https://www.culturalfoundation.eu/library/cultural-policies-algeria [last accessed 20 March 2019].

Renate Heilmeier, "Questionnaire on Goethe-Institut Damaskus im Exil," received by Ruba Totah, 22 June 2017.

Sabine Hess, "De-naturalising transit migration. Theory and methods of ethnographic regime analysis," Population, Space and Place, 2010, Vol. 18(4), p. 428-440.

Sabine Hess, "Border Crossing as Act of Resistance: The Autonomy of Migration as Theoretical Intervention into Border Studies," In Martin Butler, Paul Mecheril, Lea Brenningmeyer (eds.), Resistance, Subjects, Representations, Contexts, Bielefeld, Bielefeld Verlag, 2017, p.87-100.

Sabine Hess and Bernd Kasparek, "Under Control? Or Border (as) Conflict: Reflections on the European Border Regime," Social Inclusion, 2017, Vol. 5(3), p.58-68.

Cindy Horst and Katarzyna Grabska, "Flight and Exile-Uncertainty in the Context of Conflict-Induced Displacement," Social Analysis, 2015, Vol. 59 (1), p.1-18. 
Henk Van Houtum, Olivier Thomas Kramsch, and Wolfgang Zierhofer, Bordering Space, Burlington, VT: Ashgate, 2005.

Basma El Husseiny, "حال الفنون." Website, Jadaliyya, 15 February 2018, available at: http://www.jadaliyya.com/Details/35206/حال-الفنون [last accessed 6 April 2019].

Maja Janmyr, “The legal status of refugees in Lebanon,” Working Paper, Beirut, Issam Fares Institute for Public Policy and International Affairs, 2016, p.1-20, available at: https://www.aub.edu.lb/ifi/Documents/publications/working_papers/2015-2016/20160331_ Maja_Janmyr.pdf [last accessed 20 March 2019].

Rania Jawad, Theatre Encounters: A Politics of Performance in Palestine, New York University, 2013.

Sally Abi Khalil and Valentina Bacchin, "Lebanon: Looking ahead in times of crisis," Oxfam Discussion Papers, Beirut, Oxfam, 2015, p.1-40, available at: https://oi-files-d8-prod.s3.eu-west-2.amazonaws.com/s3fs-public/file attachments/dp-lebano n-looking-ahead-time-crisis-141215-en O.pdf [last accessed 21 March 2019].

Lebanon Support, "Formal Informality, Brokering Mechanisms, and Illegality. The Impact of the Lebanese State's Policies on Syrian Refugees' Daily Lives," Beirut, Civil Society Knowledge Centre, 2016, available at: https://civilsociety-centre.org/resource/formal-informality-brokering-mechanisms-and-illegalit y-impact-lebanese-state\%E2\%80\%99s-policies [last accessed 21 March 2019].

Susan F. Martin, Rochelle Davis, Grace Benton, and Zoya Waliany, "International Responsibility-Sharing for Refugees,” Knomad Working paper, 2018, Vol. 1(32), p.1-46.

Al Mawred Al Thaqafy, Website, Al Mawred Al Thaqafy, available at: http://mawred.org/ [last accessed 27 February 2019].

Daniel Meier, "Introduction to the Special Issue: Bordering the Middle East,"Geopolitics, 2018, Vol. 23(3), p. 495-504.

Mona Merhi, "Syrian Art Production Support Models and Sustainability Challenges," Website, Ettijahat, December 2018, available at: https://www.ettijahat.org/page/801[last accessed 21 March 2019].

Mirjana Morokvasic, "Transnational Mobility and Gender: A View from Post-wall Europe," Crossing Borders and Shifting Boundaries, 2003, Vol. 1, p.101-133.

Gerhard Riemann and Fritz Schütze, "Trajectory" as a basic theoretical concept for analyzing suffering and disorderly social processes," in D. R. Maines (ed.), Social organization and social process: essays in honor of Anselm Strauss, New York, De Gruyter, 1991, p.333-357. 
Samer Al Saber," Stages of Homeland: Remembered Ghosts - Haunted Memories," Website, Jadaliyya, April 2017, available at: https://www.jadaliyya.com/Details/34147/Stages-of-Homeland-Remembered-Ghosts-\%E2\%80 \%93-Haunted-Memories [last accessed 6 April 2019].

Robert David Sack, Human Territoriality: Its Theory and History, Cambridge, Cambridge University Press, 1986.

Matthis Schick et. al, "Challenging future, challenging past the relationship of social integration and psychological impairment in traumatized refugees," European Journal of Psycho-traumatology, 2016, Vol. 7, p.1-9.

Nina Glick Schiller, “Theorizing Transnational Migration in Our Times," Nordic Journal of Migration Research, 2018, Vol. 8(4), p. 201-212.

Carole AlSharabati and Jihad Nammour, "Survey on Perceptions of Syrian Refugees in Lebanon," Beirut, Institut Des Sciences Politiques - USJ, 2015, available at: https://data2.unhcr.org/en/documents/download/45083 [last accessed 21 March 2019].

Azadeh Sharifi," Theatre and Migration Documentation, Influences and Perspectives in European Theatre," Independent Theatre in Contemporary Europe, Bielefeld, transcript Verlag, 2017.

Erik Snel, Godfried Engbersen, and Arjen Leerkes, "Transnational involvement and social integration," Global Networks, 2006, Vo.l 6(3), p. 285-308.

Steve Spencer, Race and ethnicity: Culture, identity, and representation, Abingdon, Routledge, 2014.

Kimiko Suda, “A Room of One's Own: Highly Educated Migrants Strategies for Creating Home in Guangzhou,” Population, Space and Place, 2014, Vol. 22(2), p.146-157.

Vasiliki Theocharidou, Gary Clapton, and Lorraine Waterhouse, "Lost in Transition? Lived Experiences of Unaccompanied Afghan Minors in Greece," Master's thesis, Edinburgh, University of Edinburgh, 2016, available at: https://era.ed.ac.uk/handle/1842/22944 [last accessed 20 February 2019].

Divya Tolia-Kelly, "Locating processes of identification: Studying the precipitates of re-memory through artifacts in the British Asian home," Transactions of the Institute of British Geographers, 2004, Vol. 29(3), p.314-329. 
Ruba Totah, "Performing Arts and Social Change under Colonialism in in Palestine during the period 1960-2012: view on impact of religiosity and class on gender relations in performing art," Thesis, Birzeit, Birzeit University, 2013, available at: https://fada.birzeit.edu/bitstream/20.500.11889/1424/1/thesis 13102015 92219.pdf [Last accessed 6 April 2019].

Ruba Totah and Krystel Khoury, "Theater against Borders: 'Miunikh-Damaskus'-A Case Study in Solidarity," Arts, 2018, Vol. 7(4), p. 90.

Lisa Wedeen, Ambiguities of Domination: Politics, rhetoric, and symbols in contemporary Syria: With a new preface, Chicago, The University of Chicago Press, 1999.

Randy William Widdis, "Crossing an intellectual and geographic border: the importance of migration in shaping the Canadian-American borderlands at the turn of the twentieth century," Social Science History, 2010, Vol. 34(4), p.445-497.

Matthias Wingens, A Life-course Perspective on Migration and Integration, Dordrecht, Springer, 2011. 